\title{
PENINGKATAN MOTIVASI MENULIS ANAK USIA 5-6 TAHUN MELALUI PENGGUNAAN MEDIA KOMIK
}

\author{
Andini Diana Juliati \\ e-mail: ade.dwi.utami@gmail.com \\ PG PAUD Universitas Negeri Jakarta
}

\begin{abstract}
Abstrak: Penelitian ini bertujuan untuk meningkatkan motivasi menulis anak usia 5-6 tahun melalui penggunaan media komik. Penelitian ini dilaksanakan di PAUD Ceria Cempaka Jakarta Timur pada bulan Mei hingga Juni 2013. Metode yang digunakan adalah penelitian tindakan kelas yang dilakukan melalui dua siklus, siklus terdiri atas perencanaan, tindakan, pengamatan, dan refleksi. Pengumpulan data menggunakan non tes untuk memperoleh data tentang pelaksanaan tindakan yaitu melalui teknik observasi yaitu berupa catatan lapangan, lembar pemantau tindakan, catatan wawancara, dan catatan dokumentasi. Analisis persentase data yang digunakan dalam penelitian ini berdasarkan kesepakatan peneliti dan kolabolator adalah dengan menggunakan peningkatan $25.38 \%$ dan persentase kenaikan diakhir siklus mencapai $78.59 \%$. Berdasarkan peningkatan persentase dari penelitian ini, maka dapat dinyatakan bahwa hipotesis tindakan diterima. Maka dapat disimpulkan bahwa penggunaan media komik dapat meningkatkan motivasi menulis anak usia 5-6 tahun.
\end{abstract}

Kata-kata Kunci: Meningkatkan Motivasi, Motivasi Menulis, Anak Usia 5-6 Tahun

\section{IMPROVING THE WRITING MOTIVATION OF 5 -6 YEARS' CHILDREN THROUGH COMIC MEDIA}

\begin{abstract}
The purpose of this research is to improve the motivation to write for chidren aged 5-6 years through the application of the Comic medium. The research was implemented on PAUD Ceria Cempaka East Jakarta on May-June 2013. The method that used is class action research conducted through two cycles, a cycle of comprising planning, action, observation and reflection. The subject of research is a whole children aged 5-6 years student PAUD Ceria Cempaka that numbered 16 students. Data collection using non tests to obtain data about implementation of the actions and results of student data that motivation to write through observation tecniques that include field notes, monitoring actions, note sheets interview, and note the documentation. Analysis of the percentage of the data used in this study was based on an agreement with a researcher and collaborator is using increased $25.38 \%$ and the percentage of increase in the end of the cycle reaches $78.59 \%$. Based on the increase in the percentage of this research, it can be stated that the hypothesis is accepted. Then it can be concluded that the application of the comic medium can improve the results of motivation to write for chidren aged 5-6 years.
\end{abstract}

Keywords: Increasing Motivation, Motivation to Write, Children Age 5-6 Years

\section{PENDAHULUAN}

Bahasa merupakan alat penyampaian informasi antarmanusia. Bahasa memungkinkan anak untuk menerjemahkan pengalaman dalam simbol-simbol yang dapat digunakan untuk berkomunikasi dan berpikir. Selain itu, bahasa juga dapat diekspresikan melalui bicara, tulisan, dan gerak tubuh. Aspek bahasa terdiri atas menyimak, berbicara, membaca, dan menulis. Dalam hal ini salah satu aspek bahasa yaitu menulis akan dibahas lebih lanjut.

Kemampuan dasar menulis pada anak harus dikembangkan sebelum anak dapat menulis dengan benar. Anak tidak dapat secara langsung menguasai kemampuan menulis begitu saja. Ada tahapan yang harus dilalui agar kemampuan menulis dapat dikuasai anak secara optimal tanpa meninggalkan satu atau lebih tahapan kemampuan menulis. Cara mengembangkan kemampuan menulis dengan memberikan berbagai kegiatan yang dapat menstimulasi kemampuan menulis serta kegiatan yang menguatkan otot halus .

Berbagai macam upaya pengembangan bahasa termasuk kemampuan menulis dapat dilakukan melalui pendidikan prasekolah. Salah satu kegiatan pengembangan bahasa anak yang dilakukan di lembaga prasekolah yaitu dengan memberikan 
stimulasi menulis permulaan. Pemberian stimulasi menulis permulaan dimulai dari pemberian stimulasi motorik halus seperti bermain playdough, finger painting, ubleg, meremas sponge, dan sebagainya. Stimulasi tersebut diberikan sebagai latihan kekutan jari anak memegang pensil untuk menulis.

Pemberian stimulasi motorik halus yang tepat memberikan dampak positif pada kesiapan anak memegang pensil. Dengan demikian hal tersebut memudahkan anak untuk menulis permulaan. Stimulasi menulis permulaan dimulai dari anak mencoret-coret tanpa makna lalu akan meningkat tahapannya sampai menulis yang bermakna. Lembaga prasekolah mengajarkan anak dimulai dari menulis huruf dilanjutkan dengan menulis kata namun hanya dengan menggunakan media kertas dan pensil.

Pemberian stimulasi menulis yang tepat pada lembaga prasekolah diharapkan anak dapat mengembangkan motivasi menulis kata. Motivasi menulis kata dipergunakan agar anak mau menulis. Motivasi menulis dipengaruhi faktor dari dalam dan luar diri anak. Motivasi menulis dalam diri anak dapat ditumbuhkan apabila ada dorongan dari luar diri anak atau lingkungan. Salah satu hal yang dapat memberikan motivasi menulis dari luar diri anak yaitu dengan kegiatan menulis bermakna dan menyenangkan yang diciptakan oleh guru di sekolah.

Motivasi anak agar mau menulis dipengaruhi oleh faktor internal dan eksternal. Faktor internal berarti keinginan menulis yang muncul dari dalam diri anak. Faktor eksternal berarti motivasi dapat dimunculkan dari lingkungan. Hargai usaha anak, sebagai pendidik dan orang tua memberikan pujian terhadap hasil karya yang telah dibuat anak. Berikan dorongan dan motivasi agar anak percaya diri akan kemampuannya.

Motivasi menulis anak dapat menjadi salah satu penentu keberhasilan berlangsungnya kegiatan menulis di sekolah. Motivasi menulis anak biasanya akan menurun bila media menulis terbatas berupa buku tulis dan pensil. Kreativitas guru diperlukan dalam menciptakan kegiatan menulis yang menarik untuk anak.

Permintaan orang tua adalah meminta guru untuk meningkatkan kegiatan latihan menulis kepada anaknya di sekolah. Permintaan tersebut disanggupi oleh guru PAUD Ceria Cempaka. Setiap hari anak diberikan kegiatan menulis. Anak menggunakan buku tulis dan pensil sebagai media menulis. Namun kegiatan menulis yang diberikan belum sesuai dengan karakteristik anak usia 5-6 tahun yang merupakan anak usia dini.

Kegiatan menulis yang diberikan oleh guru di
PAUD Ceria Cempaka diantaranya adalah menulis huruf yang sama dari baris satu sampai baris sepuluh di buku tulis. Pada kegiatan tersebut guru hanya memberi contoh satu huruf pada baris atas dan kemudian anak diminta untuk meniru dengan cara menulis dibawahnya. Kegiatan menulis huruf dilakukan mulai dari menulis huruf "a" sampai dengan huruf " $z$ ". Bila menulis huruf sudah dilakukan setiap hari maka kegiatan untuk hari berikutnya adalah menulis sebuah kata.

Berdasarkan hasil pengamatan peneliti terhadap kegiatan menulis di PAUD Ceria Cempaka rendahnya motivasi anak untuk mengikuti kegiatan menulis disebabkan oleh beberapa hal seperti kegiatan menulis yang tidak variatif, media yang digunakan tidak menarik, kurangnya motivasi anak menulis, anak cepat bosan, serta kurangnya persiapan anak untuk memegang pensil. Cara guru mengajar yang tidak bervariasi yaitu dengan memberi contoh menulis huruf sekali di papan tulis kemudian anak dibagikan buku tulis dan pensil untuk mencontoh huruf yang telah dicontohkan. Begitu juga cara guru mengajar untuk latihan menulis kata dan huruf. Kurangnya pengamatan guru kepada anak saat kegiatan berlangsung karena guru hanya duduk di depan kelas. Anak yang mengalami kesulitan dalam mengikuti kegiatan hanya mencoret-coret tidak beraturan pada buku tulis dengan pensil. Ada juga anak yang mengobrol dan bercanda. Anak terlihat kurang tertarik untuk mengikuti kegiatan.

Terkait dengan pembelajaran di PAUD, motivasi menulis bisa dimunculkan dengan memberikan variasi kegiatan dan media dalam menulis. Media yang kreatif dan menarik digunakan sebagai sarana anak menulis. Kegiatan untuk menstimulasi juga harus bervariasi dan menyenangkan untuk anak usia dini. Untuk meningkatkan motivasi menulis diperlukan inovasi atau perubahan yang dilakukan oleh guru dalam cara mengajar dan pembuatan media.

Komik dianggap sebagai media pembelajaran yang dapat menjadi alat untuk meningkatkan motivasi menulis kata. Alur cerita yang dituangkan dalam panel-panel gambar akan membantu anak melihat jalan cerita. Ilustrasi-ilustrasi yang sesuai dalam sebuah komik membantu anak-anak dapat memahami sebuah cerita. Pemahaman cerita pada gambar dapat membantu anak untuk menuliskan dialog pada balon kata. Komik dapat menjadi media yang menarik, mudah dan menghibur, dalam penyampaian pembelajaran. Dengan demikian maka penelitian ini difokuskan pada peningkatan motivasi menulis melalui penggunaan media komik pada anak usia 5-6 tahun di PAUD Ceria Cempaka, Cipayung, Jakarta Timur. 


\section{Motivasi Menulis}

Motivasi mempengaruhi tindakan seseorang. King (2013:316) menyatakan motivation is the force that moves people to behave, think, and feel the way they do. Motivasi adalah kekuatan yang menggerakkan orang untuk berperilaku, berpikir, dan merasakan apa yang mereka lakukan. Terlihat jelas bahwa motivasi membentuk perilaku seseorang. Motivasi internal datang dari dalam diri seseorang. Penjelasan Santrock (2005:316) mengenai motivasi internal dan eksternal yaitu, a motivation based on internal factors, such as self determination, curiosity, challenge, and effort and a motivation that involves external incentives, such as rewards and punishments. Artinya adalah motivasi yang datang dari dalam diri karena dipengaruhi oleh beberapa faktor, seperti tekad diri, rasa ingin tahu, tantangan, usaha dan motivasi yang datang dari luar diri adalah imbalan dan hukuman. Dari faktorfaktor internal tersebut maka seseorang menjadi termotivasi untuk melakukan hal sebagai pemenuhan kebutuhan seseorang dan motivasi yang datang dari luar diri seseorang dipengaruhi oleh adanya imbalan dan hukuman dari suatu tindakan yang dilakukan seseorang.

Karakteristik perkembangan menulis anak usia 5-6 tahun merupakan gabungan dari perkembangan bahasa dan perkembangan motorik halus anak usia 5-6 tahun. Seperti yang dikutip Santrock dalam Piaget (2011:87) bahwa anak usia 2-7 tahun dalam tahap praoperasional, the child begins to represent the world with words and images, these words and images reflect increased symbolic thinking and go beyond the connection of sensory information and physical action. Anak mulai melukiskan dunia dengan kata-kata dan gambar, kata-kata dan gambar yang dilukiskan anak merupakan cerminan dari apa yang dipikirkan yang berdasarkan informasi yang telah diperoleh sebelumnya kemudian dituangkan dalam bentuk konkret melalui kegiatan fisik. Anak dapat memperoleh informasi menunjukkan bahwa anak telah mengalami perkembangan bahasa. Selain itu anak juga sudah dapat mengeluarkan pemikirannya dalam bentuk kata dan gambar semakin menunjukkan jelas bahwa anak telah mengalami perkembangan bahasa yang baik. Anak dapat menulis dan menggambar menggunakan tangannya menunjukkan bahwa anak telah mengalami perkembangan motorik halus dimana kelenturan otototot halus pada jemari dan pergelangan anak dalam memegang alat tulis.

Motivasi mempunyai peran penting dalam pembentukan tingkah laku seorang individu. Seorang individu yang mempunyai motivasi ke arah positif maka individu tersebut akan bertingkah laku positif. Begitu juga bila seorang individu mempunayi motivasi menulis maka individu tersebut akan menulis. Kemampuan menulis seorang individu perlu diajarkan sejak usia dini. Agar seorang mau menulis maka perlu ditumbuhkan dahulu motivasi menulis. Pentingnya menumbuhkan motivasi menulis pada anak agar anak termotivasi untuk mengungkapakan ekspresi melalui tulisan. Seorang anak yang sudah mempunyai motivasi untuk menulis dapat dengan mudah mengekspresikan apa yang sedang dirasakan dan dipikirkan melalui tulisan.

Berdasarkan penjelasan diatas dapat disimpulkan bahwa motivasi menulis penting diberikan pada anak. Dengan adanya motivasi menulis maka seorang anak akan tertarik untuk menulis. Anak yang mempunyai daya tarik pada kegiatan menulis akan memudahkan proses pembelajaran latihan menulis. Hasil dari latihan menulis adalah anak dapat menulis. Ketika anak sudah dapat menulis maka anak dapat mengekspresikan apa yang sedang dirasakan dan dipikirkan melalui tulisan. Motivasi menulis juga dapat meningkatkan proses latihan menulis sehingga lebih efektif.

\section{Media Komik}

Komik merupakan salah satu contoh cerita bergambar. Gambar dalam komik merupakan bentuk visualisasi dari cerita. Menurut Tedjasaputra (2007:66) yang dimaksud dengan komik adalah cerita bergambar dimana unsur gambar lebih penting daripada ceritanya. Unsur gambar pada komik sangat penting untuk memahami jalan cerita. Jalan cerita pada komik dapat dipahami meskipun tanpa adanya penjelasan berupa kata-kata. Unsur gambar pada komik mempunyai peranan penting dalam alur cerita. Hal ini juga diungkapkan oleh Tigpen (2012:15), comic strips are a group of cartoons arranged into a narrative. Komik adalah kelompok kartun yang disusun menjadi narasi. Komik merupakan kumpulan gambar yang disusun menjadi sebuah serangkaian cerita.

Terdapat unsur lain dalam komik selain gambar. Elements of comic are (2007) (1) direction, (2) bubbles, (3) caption, (4) voices, (5) visual, (6) onomatopoeia. Unsur-unsur dari komik adalah arah, gelembung, keterangan, suara, visual, onomatopoeia. Arah dalam komik merupakan alur cara membaca komik. Arah cara membaca komik biasanya dari kiri ke kanan, dimana gelembung kata sebelah kiri yang dibaca lebuh dahulu daripada sebelah kanan. Gelembung pada komik biasanya berisi kata-kata ekspresi dari tokoh dalam cerita. Keterangan pada komik biasanya penjelasan tentang narasi komik diluar dari dialog 
tokoh. Nada suara biasanya ditulis dengan bentuk kata yang dicetak tebal atau miring. Visual yang dimaksud menggambarkan latar belakang tempat cerita dari tokoh dalam komik. Onomatopoeia merupakan efek suara yang disampaikan melalui gambar seperti ada suara petir digambarkan dengan gambar petir yang sedang mengkilat.

Dari berbagai pendapat diatas terlihat umumnya komik dikenal sebagai cerita bergambar (cergam) atau diartikan sebagai cerita yang didukung oleh serangkaian gambar berurutan yang membentuk narasi. Daya tarik komik terdapat pada adanya gambar yang dapat memvisualisasikan cerita tanpa perlu mengkhayalkannya. Selain gambar terdapat pula unsur komik lain yang tidak dapat ditinggalkan. Unsurunsur yang terdapat pada komik saling mempengaruhi antara satu unsur ke unsur lainnya. Unsur-unsur itulah yang membuat komik semakin menarik untuk dibaca. Balon kata juga merupakan unsur utama yang terdpaat pada komik. Balon kata digunakan sebagai media yang melambangkan suara dalam bentuk sperti balon yang didalamnya terdapat kata-kata atau simbol-simbol tertentu. Balon kata semakin menguatkan alur cerita dalam komik.

\section{METODE PENELITIAN}

Metode yang digunakan penelitian ini adalah penelitian tindakan kelas dengan pendekatan kualitatif dan kuantitatif. Disain intervensi tindakan/rancangan siklus penelitian ini menggunakan model Nana Sudjana (2010:14). Model ini dipilih dengan alasan model ini lebih mudah dalam pelaksanaanya namun tetap dapat mencapai tujuan dari penelitian. Kegiatan pada setiap siklus tindakan terdiri atas: (a) perencanaan tindakan, (b) pelaksanaan tindakan, (c) pengamatan tindakan, (d) refleksi tindakan. Tempat pelaksanaan penelitian ini PAUD Ceria Cempaka berlokasi di Jl. Raya Cipayung No. 2, Cipayung, Jakarta Timur. Subjek penelitian ini adalah 16 anak usia 5-6 tahun yang bersekolah di PAUD Ceria Cempaka. Penelitian ini dilaksanakan pada semester 2 tahun ajaran 2012/2013 yakni, pada bulan Mei hingga Juni 2013, dengan frekuensi pembelajaran 5 kali tatap muka setiap minggu dengan 2 jam pembelajaran berdurasi 60 menit untuk kegiatan inti. Penelitian dilaksanakan 2 siklus yaitu siklus 1 sebanyak 8 kali pertemuan dan siklus 2 sebanyak 8 kali pertemuan.

Rancangan kegiatan penelitian ini sebagai berikut: (1) Perencanaan, perencanaan umum disusun berdasarkan permasalahan penelitian terkait dengan peningkatan motivasi menulis anak usia 5-6 tahun di PAUD Ceria Cempaka. Peneliti merencanakan waktu pembelajaran, rencana pembelajaran, menyiapkan media serta pedoman observasi pengumpulan data dan evaluasi. Perencanaan khusus merupakan perencanaan yang disusun untuk masing-masing siklus, seperti menyesuaikan materi yang telah disusun dalam Rancangan Pelaksanaan Pembelajaran (RPP) bersama kolaborator, menyiapkan instrumenpenelitian dan format catatan lapangan untuk melihat hasil pada setiap tindakan, menyiapkan media pembelajaran berupa komik dengan balon kata yang dikosongkan, anak akan menulis pada balon kata komik, menentukan indikator keberhasilan yang digunakan untuk mengetahui peningkatan motivasi menulis pada anak usia 5-6 tahun. Pada data penelitian, penelitian dikatakan berhasil jika mencapai keberhasilan sebesar minimal $75 \%$. Pada data pemantau tindakan, peneliti dinyatakan berhasil apabila terjadi peningkatan motivasi menulis kata saat proses pembelajaran melalui media komik; (2) Tindakan, peneliti dan kolaborator memulai pelaksanaan sesuai dengan program yang telah dirancang. Program tindakan siklus 1 terdiri atas 8 kali pertemuan masing-masing berdurasi 60 menit, yaitu 20 menit untuk pembukaan, 30 menit untuk kegiatan menulis, dan 10 menit untuk evaluasi. Selanjutnya kegiatan disesuaikan dengan waktu belajar yang dijadwalkan di sekolah tersebut. (3) Pengamatan, dilakukan oleh kolaborator terhadap pembelajaran. Hal ini dilakukan untuk meringankan tugas peneliti dalam mengamati tindakan, selain itu observasi kolaborator dilakukan agar data yang terkumpul bersifat objektif dan tidak bias; dan (4) Refleksi, mempunyai tujuan untuk menganalisa ketercapaian proses pemberian tindakan dan untuk menganalisa faktor penyebab tidak tercapainya tindakan. Refleksi dilakukan dengan membandingkan hasil pembelajaran yang dilakukan sebelum tindakan dan sesudah diberikan tindakan, sejauh mana tindakan yang diberikan berhasil. Indikaor keberhasilan dari penelitian ini adalah peningkatan motivasi menulis kata anak baik dari refleksi dalam data pemantau tindakan maupun berdasarkan data hasil penelitian. Dari hasil refleksi tersebut akan diketahui dan diputuskan tindakan berlanjut pada siklus 3 atau cukup hanya sampai siklus 2 saja.

Kisi-kisi instrumen motivasi menulis anak usia 5-6 tahun di PAUD Ceria Cempaka sebagai berikut: 1. Motivasi internal (anak memiliki tekad diri untuk mengikuti kegiatan menulis, anak memiliki rasa 
ingin tahu terhadap kegiatan menulis yang sedang berlangsung, anak menghadapi tantangan dalam kegiatan menulis, anak mempunyai usaha untuk melakukan kegiatan menulis, anak mempunyai tujuan untuk menulis, 2. Motivasi eksternal (anak menerima umpan balik dari guru). Uji validitas penelitian ini dilakukan kepada 13 anak berusia 5-6 tahun dan menggunakan expert judgement oleh seseorang yang mengerti dibidang bahasa khususnya menulis.

\section{HASIL DAN PEMBAHASAN}

Analisis data dilakukan secara kuantitatif dan kualitatif. Analisis data kuantitatif dilakukan secara terus menerus dan berkesinambungan disetiap siklus dengan presentase yang menunjukkan peningkatan. Analisis data kualitatif dilakukan dengan cara menganalisis data dari hasil catatan lapangan, catatan wawancara dan catatan dokumentasi selama penelitian berlangsung.

Secara kuantitatif, berdasarkan pengamatan yang dilakukan pada siklus 1, diperoleh presentase kenaikan motivasi menulis anak usia 5-6 tahun yang meliputi aspek motivasi internal dan eksternal. Dari data tersebut terlihat jelas peningkatan setiap anak dari tindakan yang diberikan sampai siklus 2. Berikut data presentase motivasi menulis anak pada pra penelitian yang dijabarkan dalam tabel 1 .

Tabel 1. Presentase Motivasi Menulis Anak pada Pra penelitian

\begin{tabular}{|c|c|c|c|c|}
\hline \multirow[b]{2}{*}{ No } & \multicolumn{3}{|c|}{ Presentase } & \multirow{2}{*}{$\begin{array}{c}\text { Presentase } \\
\text { Kenaikan }\end{array}$} \\
\hline & $\begin{array}{c}\text { Pra } \\
\text { Penelitian }\end{array}$ & $\begin{array}{c}\text { Siklus } \\
1 \\
\end{array}$ & $\begin{array}{c}\text { Siklus } \\
2 \\
\end{array}$ & \\
\hline 1 & $42.5 \%$ & $70 \%$ & $75 \%$ & $32.5 \%$ \\
\hline 2 & $42.5 \%$ & $65 \%$ & $75 \%$ & $32.5 \%$ \\
\hline 3 & $60 \%$ & $67.5 \%$ & $80 \%$ & $20 \%$ \\
\hline 4 & $65 \%$ & $72.5 \%$ & $80 \%$ & $15 \%$ \\
\hline 5 & $30 \%$ & $62.5 \%$ & $75 \%$ & $45 \%$ \\
\hline 6 & $65 \%$ & $72.5 \%$ & $80 \%$ & $15 \%$ \\
\hline 7 & $65 \%$ & $72.5 \%$ & $80 \%$ & $15 \%$ \\
\hline 8 & $65 \%$ & $72.5 \%$ & $80 \%$ & $15 \%$ \\
\hline 9 & $65 \%$ & $72.5 \%$ & $80 \%$ & $15 \%$ \\
\hline 10 & $65 \%$ & $67.5 \%$ & $80 \%$ & $15 \%$ \\
\hline 11 & $35 \%$ & $65 \%$ & $77.5 \%$ & $42.5 \%$ \\
\hline 12 & $65 \%$ & $72.5 \%$ & $80 \%$ & $15 \%$ \\
\hline 13 & $65 \%$ & $72.5 \%$ & $80 \%$ & $15 \%$ \\
\hline 14 & $65 \%$ & $72.5 \%$ & $80 \%$ & $15 \%$ \\
\hline 15 & $37.5 \%$ & $57.5 \%$ & $77.5 \%$ & $40 \%$ \\
\hline 16 & $35 \%$ & $62.5 \%$ & $77.5 \%$ & $37.5 \%$ \\
\hline $\begin{array}{c}\text { Rata-rata } \\
\text { Kelas }\end{array}$ & $54.21 \%$ & $68.59 \%$ & $78,59 \%$ & $24.38 \%$ \\
\hline
\end{tabular}

Secara keseluruhan hasil pengamatan dari prapenelitian, siklus 1 , dan siklus 2 meningkat.
Peningkatan pada masing-masing siklus antara lain $14.38 \%$ dari prapenelitian ke siklus 1 dan $10 \%$ dari siklus 1 ke siklus 2. Secara rinci peningkatan tersebut dari masing-masing anak dari prapenelitian sampai penelitian siklus 1 dan penelitian siklus 2 adalah terdapat satu anak meningkat sebesar $2.5 \%$, sembilan anak meningkat $7.5 \%$, satu anak meningkat $20 \%$, satu anak meningkat $22.5 \%$, dua anak meningkat $27.5 \%$, satu anak meningkat $30 \%$, satu anak meningkat $32.5 \%$. Peningkatan dari siklus 1 ke siklus 2 sebesar $68.59 \%$ menjadi $78,59 \%$. Secara rinci peningkatan dari tiap anak yaitu terdapat satu anak meningkat sebesar $5 \%$, delapan anak meningkat $7.5 \%$, satu anak meningkat $10 \%$, empat anak meningkat $12.5 \%$, satu anak meningkat $15 \%$, satu anak meningkat $20 \%$.

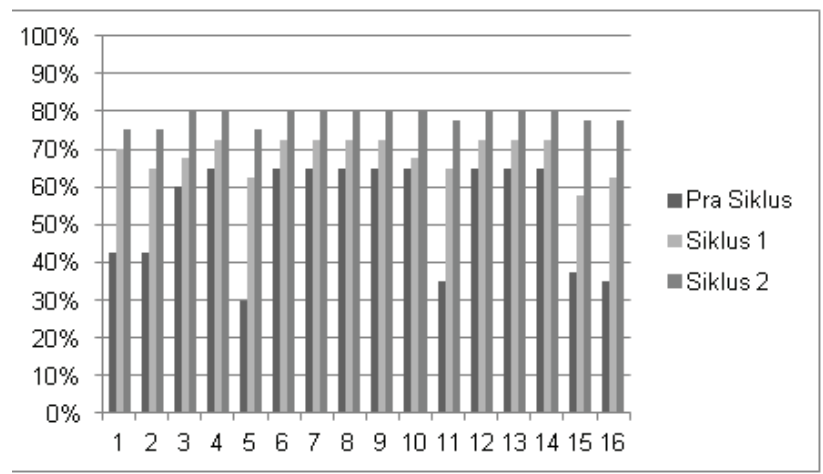

Gambar 1. Hasil Peningkatan Motivasi Menulis Anak

Peningkatan setiap anak yang terlihat dari penggambaran grafik diatas, grafik tersebut merupakan hasil penilaian sejak pra penelitian, penelitian siklus 1, dan penelitian siklus 2. Pada grafik tersebut memaparkan bahwa terdapat peningkatan yang lebih banyak dari pra penelitian sampai siklus 1 . Secara kualitatif, berdasarkan pengamatan yang dilakukan peneliti dan kolaborator pada siklus 1 dan 2 dalam kegiatan menulis komik dapat dikatakan berjalan dengan lancar. Pada pra penelitian, rata-rata motivasi menulis anak belum terlihat meningkat, anak masih terlihat belum termotivasi saat kegiatan menulis berlangsung, guru hanya duduk di depan kelas dan anak menulis di buku tulis tanpa dibantu guru, hal tersebut selalu berulang disetiap pertemuan sebelum penelitian tindakan ini berlangsung. 
Perubahan mulai terlihat setelah tindakan diberikan pada siklus 1 , motivasi menulis anak semakin meningkat. Terlihat dari data yang disampaikan, setelah tindakan siklus 1 . Motivasi menulis anak diukur dari presentase prapenelitian adalah sebesar $54.21 \%$ lalu pada siklus 1 ke siklus 1 sebesar $68.59 \%$. Motivasi menulis anak mengalami peningkatan sebesar $14.38 \%$. Motivasi menulis anak memang mengalami peningkatan dari pra penelitian sampai siklus 1 namun peningkatan tersebut belum mencapai kriteria keberhasilan penelitian yang telah disepakati oleh peneliti dan kolaborator sebesar $75 \%$.

Pada siklus 1 ini, anak diberi kegiatan menulis komik bertema pekerjaan dengan subtema guru, pilot dan pramugari, petani, tukang ojek, pemadam kebakaran, dan supir taksi. Dari keseluruhan kegiatan yang diberikan, semua anak ikut berperan serta, anak yang pemalu mulai percaya diri. Tindakan yang diberikan secara berulang setiap harinya memberi dampak pada perubahan perilaku anak yang kemungkinan motivasi menulis anak usia 5-6 tahun meningkat, seperti anak yang duduk di dalam kelas selama kegiatan menulis, anak yang bertanya kepada guru mengenai kegiatan menulis, anak mengikuti kegiatan menulis, anak menulis secara individu sesuai instruksi guru, anak menulis secara berkelompok sesuai instruksi guru, anak mengambil pensil untuk menulis, anak menulis pada media yang disediakan guru, anak mengikuti instruksi guru untuk menyelesaikan latihan menulis. Pada siklus 1 ini, masih terdapat beberapa anak yang mengalami kesulitan untuk fokus atau masih suka bermain-main dalam kelas saat kegiatan menulis.

Peningkatan motivasi menulis anak pada siklus 2 ditunjukkan dengan anak melakukan tindakan yang menunjukkan motivasi menulis tanpa diberi instruksi oleh peneliti. Anak-anak mengambil pensil dengan sendirinya, tidak ada anak-anak yang keluar kelas saat kegiatan menulis berlangsung, semua anak mengikuti kegiatan menulis, anak-anak menyelesaikan komik yang ditulis sesuai instruksi peneliti. Presentae pada siklus 2 dapat terukur sebesar $78.59 \%$. Hal ini menunjukkan kenaikan presentase sebesar $10 \%$ dari siklus 1. Delapan pertemuan yang telah dilaksanakan pada siklus 2 ini memberikan penguatan terhadap peningkatan motivasi menulis yang sudah muncul di siklus 1.

\section{PENUTUP}

\section{Kesimpulan}

Karakteristik anak usia 5-6 tahun sudah dapat menuangkan apa yang dilihat, dirasakan, serta dipikirkan melalui tulisan. Salah satu upaya untuk meningkatkan motivasi menulis untuk anak usia 5-6 tahun dapat melalui media komik. Pada komik terdapat gambar dan balon kata sebagai ungkapan ekspresi pada gambar. melalui gambar yang dilihat pada komik anak usia 5-6 tahun tersebut dapat menuangkan pemahamannya dalam kata-kata yang anak tuliskan sendiri pada balon kata. Dengan demikian melalui media komik diharapakan dapat meningkatkan motivasi menulis anak usia 5-6 tahun .

Berdasarkan hasil analisis data pra-penelitian didapat presentase pra penelitian motivasi menulis anak usia 5-6 tahun di PAUD Ceria Cempaka adalah sebesar $54.21 \%$, sedangkan pada akhir siklus 1 didapat presentase motivasi menulis anak usia 5-6 tahun di PAUD Ceria Cempaka adalah sebesar 68.59\%. Dari data tersebut dapat dikatakan bahwa kenaikan presentase motivasi menulis anak usia
5-6 tahun di PAUD Ceria Cempaka pada akhir siklus 1 adalah $14.38 \%$. Sebagaimana disampaikan pada interpretasi hasil analisis bahwa penelitian ini dikatakan berhasil jika adanya ketercapaian sebesar $75 \%$ sesuai kesepakatan dengan kolabolator. Hal itu berarti kenaikan presentase yang diharapkan adalah $20.79 \%$, maka pada akhir siklus 1 ini penelitian harus dilanjutkan pada siklus 2 karena presentase kenaikan belum sesuai yang diharapkan.

Hasil pada siklus 2 diperoleh presenatase sebesar $78.59 \%$, lebih tinggi dibandingkan siklus 1 yaitu $68.59 \%$. Dari data tersebut dapat dikatakan bahwa presentase siklus 1 ke siklus 2 mengalami peningkatan pada indikator secara keseluruhan sebesar $10 \%$. Hal tersebut menunjukkan bahwa presentase kenaikan motivasi menulis anak usia 5-6 tahun di PAUD Ceria Cempaka signifikan karena terus meningkat. Demikian pula, maka dapat dinyatakan bahwa melalui penggunaan media komik dapat meningkatkan motivasi menulis anak usia 5-6 tahun di PAUD Ceria Cempaka, Cipayung, Jakarta Timur. 


\section{DAFTAR PUSTAKA}

King, L.A. (2013). The science of psychology: An appreciative view. Second Edition. New York: McGraw Hill.

Santrock, J.W. (2011). Life span development. Thirteen edition. New York: McGraw Hill.

Santrock, J.W. (2005). Psychology: Essentials, updated. Second Edition. United States: McGraw Hill.

Sudjana, N. (2010). Menyusun karya tulis ilmiah ber- basis penelitian tindakan kelas. Bekasi: LPP Binamitra.

Tedjasaputra, M.S. (2007). Bermain, mainan dan permainan untuk anak usia dini. Jakarta: Grasindo.

Tigpen, N.T. (2012). "Thesis Decoding Comic: Essential Elements for Transcriptio". Journal: Lousiana State University and Agricultural and Mechanical College. 